\title{
M.A. КРАСНОВ
}

\section{ПРЕЗИДЕНТ В СИСТЕМЕ ПУБЛИЧНОЙ ВЛАСТИ СМЕШАННОЙ МОДЕЛИ}

Авторитарный потенциал, кроющийся в институте президента, существует во всех моделях власти. Но он резко возрастает в полупрезидентской (смешанной) модели, которая от президентской республики заимствует легитимность главы государства, и от парламентской модели неопределенность его места в системе публичной власти. В парламентской системе этот фактор не играет большой роли, поскольку в обычных условиях рычаги влияния президента на иные институты власти номинальны. А вот в смешанной модели двусмысленный статус главы государства не просто способствует превращению его в мощнейшую политическую фигуру, но и может угрожать самому принципу разделения властей.

\section{Президент - глава исполнительной власти?}

Такого мнения в отношении российского Президента придерживается немало отечественных исследователей [см., например: 6, с. 96; 10, c. $190-196 ; 18 ; 27$, с. $59 ; 37$, c. $16-17 ; 43$, c. $381 ; 52$, с. $66-77 ; 54 ; 56$, c. $232-$ 234; 60, с. 31]. Аргументы можно свести к трем группам: 1) отнесение Президента РФ к исполнительной власти диктуется логикой разделения властей; 2) полномочия Президента РФ в большинстве своем характерны для исполнительной власти; 3) взаимоотношения с органами исполнительной власти свидетельствуют о том, что Президент РФ - руководитель этой ветви власти.

Аргумент: отнесение Президента к исполнительной власти диктуется логикой разделения властей.

«Конфликт» между положениями ст. 10 и ч. 1 ст. 11 Конституции РФ давно замечен в нашей литературе. Сторонники отнесения Президента к исполнительной ветви, скорее всего, так разрешают данное противоречие: государственная власть осуществляется на основе разделения на законодательную, исполнительную и судебную (ст. 10) $\rightarrow$ Президент - один из государственных органов, осуществляющих государственную власть (ст. 11) $\rightarrow$ следовательно, он должен относиться к одной из трех назван- 
ных ветвей, а наиболее естественной для Президента является ветвь исполнительной власти.

Такая позиция, скорее всего, обязана сугубо традиционному представлению о принципе разделения властей, когда именно «первое лицо» является носителем исполнительной власти. Между тем, как верно подметил В.Е. Чиркин, «в изначальной конструкции главы государства как исполнительной власти существовали изъяны. Положение главы государства уже тогда не могло быть сведено и не сводилось только к исполнительной деятельности» [61, с. 80-81], и поэтому «вряд ли в научных исследованиях и учебниках следует относить современного монарха к исполнительной власти. Он не был только исполнителем в прошлом, не является им и сейчас» $[61$, с. 81$]$.

Это верно, хотя точнее сказать, что монарх вообще не был «исполнителем» в буквальном смысле. Стоит напомнить, что термин «исполнительная власть» появляется в теории Дж. Локка применительно к человеку в его естественном (безгосударственном) состоянии. Дж. Локк хотел тем самым подчеркнуть, что естественный человек находился под действием закона природы [39, с. 268]. Однако термин этот не очень точный, так как законы природы нельзя исполнять или не исполнять, можно только от них зависеть, им подчиняться. Так что мы изначально имеем дело с условным термином (не случайно Локк употреблял слова «исполнение», «подчинение», «подотчетность» как синонимы). Тем не менее именно термин «исполнительная власть» стал относиться к лицам и органам, призванным следить «за исполнением тех законов, которые созданы и остаются в силе» [39, c. 347]. При этом Дж. Локку было важно донести идею, что народ является высшей властью, но поручает осуществлять государственную власть разным институтам. И даже называя законодательную власть верховной, он утверждал, что «верховная власть устранять или заменять законодательный орган», если «законодательная власть действует вопреки оказанному ей доверию», остается у народа [39, с. 349].

Дж. Локк не собирался доказывать, что исполнительная власть, осуществляемая королем, подчинена власти законодательной. Верховенство последней он видел не в командовании властью исполнительной, а в том, что именно она «обладает правом создавать законы для всех частей и для каждого члена общества, предписывая им правила поведения и давая силу для наказания, когда они нарушены» [39, с. 350].

Конечно, за два-три века трактовка исполнительной власти изменилась (например, в это понятие вошла и внешнеполитическая деятельность). Во всяком случае, сегодня исполнительная власть не понимается так узко.

Изменение социально-политической ситуации в западноевропейских странах и отвоевывание парламентами все новых властных прерогатив 
постепенно привели к тому, что монархи стали формировать правительство с учетом итогов расстановки политических сил, прежде всего на основе парламентских выборов [64, с. 254, 279-280]1. Так началась новая стадия процесса превращения монархов в конституционных монархов современного типа. Формальное отнесение современного монарха к исполнительной власти или отсутствие такого указания перестало играть какую бы то ни было политическую роль. Ниже приведены положения европейских писаных конституций о закреплении места монарха в системе публичной власти, а в отношении Великобритании указано, какое место отводит монарху официальная доктрина.

Таблица

\section{Официальное место современных европейских монархов в системе разделения властей}

\begin{tabular}{|c|c|l|}
\hline$№$ п/п & Государство & \multicolumn{1}{|c|}{ Конституционный статус монарха } \\
\hline 1 & Бельгия & «Королю принадлежит исполнительная власть» (ст. 37) \\
\hline 2 & Великобритания & $\begin{array}{l}\text { Монарх относится к законодательной и исполнительной ветвям } \\
\text { власти }\end{array}$ \\
\hline 3 & Дания & $\begin{array}{l}\text { «Законодательная власть осуществляется совместно Королем и } \\
\text { Фолькетингом. Исполнительная власть осуществляется Коро- } \\
\text { лем» (п. 3 ч. I) }\end{array}$ \\
\hline 5 & Испания & $\begin{array}{l}\text { Король не возглавляет исполнительную власть, хотя формально } \\
\text { предлагает кандидатуру председателя Правительства, назнача- } \\
\text { ет и освобождает его от должности, может председательство- } \\
\text { вать на заседаниях Совета министров (ст. 62). Исполнительная } \\
\text { власть осуществляется Правительством (ст. 97) }\end{array}$ \\
\hline 6 & Люксембург & $\begin{array}{l}\text { Великий Герцог осуществляет исполнительную власть (ст. 33) } \\
\text { Правительство, ответственное перед Князем и парламентом } \\
\text { (ст. 78) }\end{array}$ \\
\hline 7 & Монако & $\begin{array}{l}\text { «Исполнительная власть подчинена высокой власти Князя» } \\
\text { (ст. 3) }\end{array}$ \\
\hline 8 & Нидерланды & «Правительство состоит из Короля и министров» (ст. 42) \\
\hline 9 & Норвегия & $\begin{array}{l}\text { «Исполнительная власть принадлежит Королю или Королеве...» } \\
\text { (§ 3-В) }\end{array}$ \\
\hline 10 & Швеция & Король отделен от исполнительной власти (гл. 1 и 5) \\
\hline
\end{tabular}

Итак: в семи странах из десяти король (королева) относится к исполнительной власти, а в двух - еще и к законодательной; где-то монарх возглавляет исполнительную власть, а где-то является просто ее патроном. Но все эти монархии относятся к парламентарным (парламентским), кото-

\footnotetext{
1 Этот процесс не был синхронным в разных странах Европы. Так, Б.Н. Чичерин писал, что в Британии практика формирования правительства с учетом мнения парламента возникла еще при короле Георге II в 1750-х годах, а во Франции - при Людовике XVIII в начале 1820 -х годов.
} 
рые отличаются от дуалистической монархии не столько формальными особенностями, сколько (здесь более точен А.С. Автономов) степенью ограничения королевской власти [2, с. 250]. В парламентской модели монарх остается фактически лишь главой государства, что верно отмечено А.М. Осавелюком $[45, \text { с. } 124]^{1}$.

Практически все государства проходят через стадию, когда институты, представляющие разные центры влияния, борются за властные прерогативы, стремясь если не ликвидировать противостоящий им институт, то максимально ослабить его. А усиление/ослабление института связано как раз с овладением/утратой им контроля над правительством (кабинетом). Разумеется, в этом историческом процессе возможны откаты к предшествующему состоянию, но общий тренд сохраняется.

В большинстве стран Европы процесс деконцентрации власти и борьбы за прерогативы начался в XIX в. и завершился в XX в. Именно поэтому дуалистическую монархию часто называют переходной, промежуточной $[29$, с. $343-344 ; 42$, с. 76$]$ : за ней наступила эра монархии, названной парламентской.

Современник этого процесса выдающийся правовой мыслитель Б.Н. Чичерин в монографии, изданной в 1866 г. на основе его докторской диссертации, отмечал естественность процесса парламентаризации, ибо «всякое представительство, имеющее некоторую силу и независимость, непременно стремится к парламентскому правлению» [64, с. 180]. Причем он утверждал, что бессмысленно и даже опасно для государства, когда правительство (а имелись в виду европейские монархи) пытается затормозить этот процесс и отделаться полумерами. Чичерин резюмировал: «Для государственных интересов нет ничего бесплоднее, как две власти, которые с опасением смотрят друг на друга, стараясь не сделать сопернику слишком значительных уступок. Поэтому, как скоро в государстве вводится представительное устройство, единственная здравая политика состоит в искреннем признании конституционных начал» [64, с. 180]. Другое дело, писал он, возможно, намекая на Россию, что «не всякое представительное собрание способно к парламентскому правлению. На это нужны весьма высокие условия и значительная политическая зрелость народа; необходимы организованные партии, умеющие вести дела в виду общих интересов» [64, с. 181].

Две крупные и экономически мощные страны - Россия и Германия отстали от европейского процесса деконцентрации монархической власти (и не потому ли поплатились впоследствии установлением тоталитарных режимов?). Как бы то ни было, к середине XX в. европейские и ряд азиат-

\footnotetext{
${ }^{1}$ Хотя он допускает некоторую неточность, говоря, что монарх в парламентарной монархии замещает только пост главы государства. Монарх не замещзает «пост главы», а является главой именно в силу того, что он - монарх.
} 
ских монархий превратились в парламентские (парламентарные), а сами монархи - в «царствующих, но не правящих», поскольку у них отбирался главный рычаг власти и влияния - реальный контроль над исполнительной властью.

Хотя образцом для президентской республики послужила британская дуалистическая монархия, положение президента уже не во всех деталях соответствовало представлениям основателей теории разделения властей. Еще больше особенностей в конструировании системы разделения властей возникло с появлением парламентской республики, образцом для которой стала парламентская монархия. Здесь президент предстает в новом статусе. Первая парламентская республика - Франция 1871 г. (первый Президент до 1873 г. - А. Тьер), хотя конституционно она была оформлена в 1875 г. Правда, Третья республика была еще только переходом к парламентской: президент, хотя и избирался парламентом, формально продолжал считаться главой исполнительной власти; к тому же французское президентство по Конституции 1875 г. было отнюдь не «церемониальным».

Рождение еще одной, пожалуй, самой своеобразной модели, закрепленной сначала в Веймарской Конституции 1919 г. и впоследствии (уже во Франции) названной полупрезидентской республикой (смешанным, или полупрезидентским режимом), вполне соответствовало духу времени, но ее конкретные очертания обязаны германской истории (как минимум, начиная с Бисмарка) ну и, конечно, своеобразию той ситуации, которая сложилась в Германской империи после Первой мировой войны. Как пишут В.Г. Баев и Е.С.Ч. Ковальски, данная модель обусловлена прежде всего «спецификой позднего становления германской государственности и наличием мощной монархической традиции» [7, с. 310].

Историческая логика, казалось бы, требовала, чтобы Германия стала парламентской республикой, как бы продолжая линию, вынужденно обозначенную кайзером [45, с. 408] $]^{1}$. Однако та самая «мощная монархическая традиция» потребовала введения сильной фигуры президента. В то время это не рассматривалось как создание новой разновидности республиканской формы правления. Но это была именно новая модель, едва ли не главной особенностью которой является, с одной стороны, усиление политического влияния президента благодаря всеобщим выборам, с другой - его институциональное отделение от исполнительной власти.

Итак, система разделения властей в зависимости от исторических, социально-политических и иных условий постоянно развивалась и видоизменялась. За несколько сот лет модификации этой системы стали на-

\footnotetext{
1 За месяц до своего отречения кайзер Вильгельм II 30 сентября 1918 г. «своим указом практически ввел в действие парламентскую систему».
} 
столько разнообразными, что, не учитывая конкретное конституционное положение монарха или президента, в том числе его компетенцию, невозможно утверждать об обязательности его вхождения в состав исполнительной власти.

Аргумент: полномочия Президента РФ в больиинстве своем характерны для исполнительной власти.

Ю.Н. Старилов пишет, что главная задача органов исполнительной власти - «правоисполнительная деятельность, т.е. исполнение действующих законов и иных нормативных правовых актов, а также обеспечение их выполнения всеми субъектами права» [52, с. 42]. Не буду долго останавливаться на том, что такое утверждение похоже на тавтологию и что вообще-то органы исполнительной власти обязаны исполнять/обеспечивать исполнение не только нормативных, но и индивидуальных правовых актов, например судебных решений. Я не согласен с этим утверждением в другом. Термин «исполнение» можно трактовать как одну из форм реализации права $[3$, с. $251-254 ; 14$, с. 93 ; 30, с. 37 ; 40, с. 88-89, 92, 99; 47, с. 27; 55 , с. $200 ; 59$, с. 384$]$, применимую ко всем субъектам права, относящимся к разным ветвям власти (например, Государственная Дума РФ исполняет закон, когда рассматривает проект государственного бюджета, а Президент РФ - когда обращается к парламенту с ежегодным посланием). Следовательно, «правоисполнительная деятельность» не специфична исключительно для исполнительной власти.

Вообще, думаю, исследователей вводит в заблуждение терминология, которая, как уже замечено, сама по себе условна. Да, власть, олицетворяемую королем, Дж. Локк назвал исполнительной, а короля - «верховным исполнителем закона»[39, с. 350]. Но только для того, чтобы противопоставить понятие «исполнение» понятию «выработка правил». Кстати, в британской доктрине такое разделение сохранилось: исполнительная власть «не допускается» к выработке нормативных актов. Собственно, первоначальная идея разделения властей заключалась именно в разъединении нормотворчества и правления (повседневного управления). Не случайно Локк еще не выделял отдельной судебной власти, оставляя отправление правосудия за королевской властью [39, с. 387]. Ему было принципиально важно показать необходимость разделения законотворчества и управления, но одновременно подчеркнуть неразрывность обоих видов государственной деятельности: «Ведь законы создаются не ради самих законов, но для того, чтобы они выполнялись и тем самым служили узами, связывающими общество, чтобы держать все части политического тела в надлежащих местах и при надлежащем функционировании; когда это полностью прекращается, то явно прекращается и правление и народ становится беспорядочной массой, лишенной всякого порядка и связи. Там, где не продолжается более отправление правосудия для обеспечения 
прав людей и в обществе не остается какой-либо власти, которая направляла бы его силу или обеспечивала бы нужды населения, там, несомненно, не остается и правительства. Когда законы не могут исполняться, то это все равно как если бы законов не было <...>» [39, с. 387-388].

Здесь речь идет не о том, что исполнительная власть предпринимает лишь те действия, которые предписаны в законах, а о том, что повседневное управление должно осуществляться на основе закона. Тем самым в государстве действует правовой порядок, антитеза которому анархия (или диктатура, сказал бы я). Именно поэтому точнее говорить не об исполнительной, а об управительной (управляющей) или, как ее порой называли раньше, правительственной власти [28, с. $137-138 ; 34$, с. $314 ; 63$, с. 89 , $159,162]$.

Тут важно, что термин «правительственная власть» применяется как к личностям (прежде всего монархам), так и к коллегиям (кабинетам), т.е. под понятием «ветвь власти» понимается не вся система государственных органов, а орган (лицо), который эту систему олицетворяет, возглавляет. Статья 11 Конституции РФ гласит, что государственную власть в России осуществляют Президент, Федеральное Собрание, Правительство и суды Российской Федерации. Но при этом «исполнительную власть Российской Федерации осуществляет Правительство Российской Федерации» (ч. 1 ст. 110 Конституции РФ), а не система органов исполнительной власти. Таким образом, даже этот формальный момент должен показать, что, коль скоро исполнительная власть принадлежит правительству, она не может одновременно принадлежать и президенту.

Такой вывод подтверждается и тем, что, согласно ч. 1 ст. 115 Конституции РФ, Правительство издает постановления и распоряжения, обеспечивает их исполнение «на основании и во исполнение Конституции Российской Федерации, федеральных законов, нормативных указов Президента Российской Федерации» и что последний вправе отменить акты правительства в случае их противоречия не только Конституции и законам, но и президентским указам (ч. 3 ст. 115). Таким образом, акты президента РФ для правительства (исполнительной власти) приравниваются к законодательству, а сам Президент является для этой ветви власти «внешним агентом».

Из такого же понимания главы государства исходил Б. Констан, утверждавший: «Правительственная власть хотя и проистекает из власти королевской, имеет тем не менее действительно отдельное от последней существование: различие между властью, облеченной неприкосновенностью, существенно и фундаментально» [28, с. 138].

Не свойственны Президенту РФ и конкретные признаки исполнительной власти. Д.Н. Бахрах выделяет десять таких признаков [10, с. 5153]. Правда, в большинстве своем они либо не специфичны, т.е. характер- 
ны не только для органов исполнительной власти (например, контроль за исполнением законов или их конкретизация), либо являются слабо формализуемыми и зависимыми от политического режима. Но в его перечне есть три признака (хотя и их формулировки небезупречны), которые, думаю, действительно, специфичны именно для исполнительной власти.

Первый - систематическая, непрерывная деятельность, направленная на сохранение социальной системы, ее укрепление и развитие $[10$, c. 51$]$. Когда люди в повседневной жизни сталкиваются, контактируют с государством, оно предстает в лице либо прямых представителей исполнительной власти (например, полицейских), либо тех, кто работает в уч-

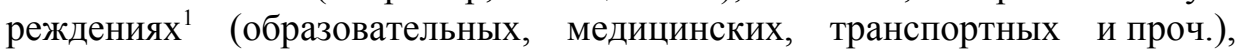
управляемых органами исполнительной власти. Стоит вспомнить, как классики теории разделения властей смотрели на признак непрерывности.

Дж. Локк утверждал: «Нет никакой необходимости и даже нет большого удобства в том, если законодательный орган будет действовать непрерывно. Однако это абсолютно необходимо для исполнительной власти: ведь не всегда имеется нужда в создании новых законов, но всегда необходимо выполнять те законы, которые созданыл [39, с. 350]. О том же писал и Ш. де Монтескье: «Нет никакой надобности в том, чтобы законодательное собрание было постоянно в сборе. Это было бы неудобно для представителей и слишком затруднило бы исполнительную власть, которой в таком случае пришлось бы заботиться уже не о том, чтобы выполнять свои обязанности, а лишь о том, чтобы защищать свои прерогативы и свое право на исполнительную деятельность» [41].

Другими словами, только для органов исполнительной власти наиболее естественно оперативно реагировать на любые сбои в работе государственного механизма, любые (внутренние и внешние) угрозы его стабильному функционированию. Такие органы, следовательно, должны обладать возможностями постоянного (повседневного) мониторинга всех социальных процессов, подведомственных государству, полномочиями пo выявлению и пресечению покушений на такой порядок.

Президент в смешанной модели не имеет не только задачи, но и возможностей заниматься систематическим и непрерывным управлением, поскольку этот институт не представляет собой систему публичновластных органов. У него есть полномочные представители (в федеральных округах или в некоторых органах государственной власти). Но они не составляют такую систему и, главное, не имеют публично-властных полномочий. Не случайно для того, чтобы наделить некоторых своих представителей такими полномочиями, Президент создает не соответствую-

\footnotetext{
${ }^{1}$ В советское время сотрудников такого рода учреждений относили к государственным служащим. Сегодня они неофициально именуются «бюджетниками».
} 
щий Конституции РФ симбиоз, соединяя должности вице-премьера с должностью полномочного представителя Президента РФ ${ }^{1}$. Однако российское законодательство четко разводит государственные должности (для непосредственного исполнения полномочий государственных органов) и должности государственной гражданской службы (для обеспечения исполнения полномочий государственных органов, лиц, замещающих государственные должности) $)^{2}$. В данном же случае Президент соединил в одной должности лицо, замещающее государственную должность, и государственного служащего.

Собственно, в распоряжении Президента РФ есть всего два государственных органа. Первый - его Администрация, которая, однако, не является органом государственной власти, т.е. ее решения и действия деятельность не создают, не изменяют и не прекращают публично-правовые отношения. Администрация - всего лишь annapam Президента. Второй орган - Аппарат Совета Безопасности РФ, причем даже сам Совет Безопасности не обладает публично-властными полномочиями, он законодательно назван «конституционным совещательнымм» органом ${ }^{3}$.

По мнению С.А. Осетрова, «президентская власть в отличие от системы исполнительной власти не занимается вопросами оперативного управления в процессе реализации принимаемых государственных решений» [46, с. 38]. Действительно, Президент РФ осуществляет управление, так сказать, точечно, а такой «режим деятельности» не свойствен органу исполнительной власти.

Признаком исполнительной власти Д.Н. Бахрах считает также деятельность, «в процессе осуществления которой издается огромное количество распоряжений - административных актов» [10, с. 52]. Уточню: термин «административный акт» применен здесь, скорее, в том смысле, какой ему придает немецкая теория административного права - как индивидуальный юридический акт, создающий, изменяющий или прекращающий административно-правовые отношения. Французская же теория включает в это понятие также нормативные акты, изданные органами исполнительной власти, или правовые акты управления [53, с. 46-47].

\footnotetext{
${ }^{1}$ См.: Указ Президента РФ от 15 октября 1999 г. № 1380 «О Заместителе Председателя Правительства Российской Федерации - полномочном представителе Правительства Российской Федерации в Чеченской Республике» и Указ Президента РФ от 12 июля 2012 г. № 976 «О внесении изменений в некоторые акты Президента Российской Федерации». Все нормативные правовые акты и судебные решения проанализированы с помощью Справочной правовой системы «КонсультантПлюс».

${ }^{2}$ См. ст. 1, 4, 5 Федерального закона от 27 мая 2003 г. № 8-Ф3 «О системе государственной службы Российской Федерации», ст. 1, 3 Федерального закона от 27 июля 2004 г. «О государственной гражданской службе Российской Федерации».

${ }^{3}$ См. ст. 13 Федерального закона от 28 декабря 2010 г. № 390-Ф3 «О безопасности».
} 
Во-первых, нельзя говорить об «огромном количестве распоряжений» Президента РФ. Так, согласно справочно-правовой системе «КонсультантПлюс», например, с 1 января 2012 г. по 31 декабря 2017 г. было издано 1262 президентских распоряжения, тогда как распоряжений Правительства РФ за тот же период вышло в десять раз больше - 13 263. Вовторых, президентские распоряжения касаются, как правило, не публичных, а сугубо аппаратных вопросов. Наконец, в-третьих, до принятия действующей Конституции РФ 1993 г. Президент РФ нередко издавал распоряжения, которые действительно, можно считать административными актами ${ }^{1}$. Но тогда он официально считался высшим должностным лицом и главой исполнительной власти. Хотя редко, но и после 1993 г. Президент РФ также издает распоряжения, носящие характер административных актов. Однако это, на мой взгляд, выходит за рамки его конституционной компетенции.

Наконец, к признакам исполнительной власти Д.Н. Бахрах относит возможность «самостоятельно осуществлять физические, организационные и иные меры принуждения в административном порядке» $[10$, c. 52]. В президентской компетенции мы не найдем такого элемента. Конечно, если широко трактовать понятие «государственное принуждение», то можно сказать, что он осуществляет его, приказывая ввести войска в какой-то регион страны для подавления мятежа. Но и в этом случае президент действует не в административно-, а в конституционно-правовом порядке. Он не может наложить штраф, арест, иную меру административной ответственности; официально он не вправе даже поручить привлечь какоето должностное лицо к уголовной или административной ответственности.

Но ведь, скажут, у правительства тоже нет полномочий по применению мер административного принуждения, но именно оно реализует исполнительную власть. Верно. Тут уместна аналогия с президентами в президентской модели: президенты, которые возглавляют исполнительную власть, тоже не применяют меры административного принуждения. Кстати, они также мало напоминают орган исполнительной власти, что отмечал, в частности, Вудро Вильсон [67, с. 66]. Разница, однако, состоит в том, что в отличие от президента в смешанной модели именно они официально руководят исполнительной властью и несут за это политическую ответственность.

И тут я должен вновь вернуться к ст. 114 Конституции РФ, которая закрепляет компетенцию Правительства РФ. Эта статья вроде бы побуждает согласиться с тем, что схожесть задач и полномочий Правительства с

\footnotetext{
${ }^{1}$ Таковы, например, распоряжения Президента РФ: от 28 декабря 1991 г. № 132-рп «О приватизации государственного имущества в Московской области»; от 14 июля 1992 г. № 363-рп «Об осуществлении функций государственной экспертизы полезных ископаемых».
} 
задачами и полномочиями Президента РФ является подтверждением, будто последний относится к исполнительной власти. Однако, как ни парадоксально, это служит как раз одним из свидетельств разной природы правительства и президента.

Системный анализ показывает: Конституция РФ имеет в виду, что Президент действует не как глава исполнительной власти, а как ее политический патрон. И тогда иначе воспринимается и п. «ж» ч. 1 ст. 114 Конституции РФ, согласно которому Правительство осуществляет иные полномочия, которые возлагаются на него не только Конституцией и законами, но и указами Президента, которые одновременно являются и рамками деятельности Правительства наряду с самой Конституцией РФ и федеральными законами (ст. 115). Если бы Президент был главой исполнительной власти, Конституция не устанавливала бы таких правил.

Нельзя отнести к исполнительно-распорядительным и такие президентские полномочия, перечисленные в ст. 89 Конституции РФ, как решение вопросов гражданства, предоставление политического убежища, помилование, награждение, присвоение почетных званий, высших воинских и высших специальных званий. Их характер указывает на то, что речь идет опять же не об управлении в административно-правовом смысле этого понятия, прежде всего потому, что президент при реализации таких полномочий предстает как высший представитель государства. Именно поэтому невозможно говорить о каких-то «правах» получателей соответствующих «благ» и об «обязанности» главы государства предоставлять эти «блага». Хотя процесс, предшествующий решению Президента, включает в себя принятие юридических актов и совершение действий органов исполнительной власти (например, по вопросам приобретения гражданства), и эта деятельность довольно подробно регулируется, окончательное (политическое) решение зависит от Президента. И если лишить его политической дискреции, конституционно-правовой смысл данных полномочий утрачивается.

Аргумент: взаимоотношения с органами исполнительной власти свидетельствуют о том, что Президент РФ - руководитель этой ветви власти.

Конечно, нельзя отрицать, что в полупрезидентской республике с институционально сильным президентом последний оказывает существенное воздействие на правительство. В этом отношении смешанная модель может напоминать президентскую республику (недаром некоторые исследователи не склонны различать между собой эти модели [38, c. 212$\left.]^{1}\right)$. А уж Россия представляет собой настолько яркий пример схоже-

\footnotetext{
${ }^{1}$ Например, известный французский компаративист Раймон Леже, описывая российскую систему публичной власти, не только «помещает» правительство вместе с президентом в раздел «Исполнительная власть», но и рассматривает оба этих института в параграфе, названном «Президентская система».
} 
сти с президентской моделью, что можно понять мотивы исследователей, относящих президента к исполнительной власти. О рычагах воздействия Президента РФ на правительство написано уже так много и подробно, в том числе автором настоящей статьи [см., например: $35 ; 36$ ], что нет смысла воспроизводить это еще раз. Однако об основных конституционHblx нормах, обусловливающих президентский контроль над исполнительной властью, стоит напомнить.

1. Правительство (подчеркну, в полном соответствии с Конституцией РФ) находится под полным контролем исключительно Президента. Не потому, что тот единолично назначает и увольняет от должности членов Правительства (за исключением его Председателя). Это могло бы в наибольшей мере напоминать о президентской модели, если бы кандидатуры на должности заместителей председателя и федеральных министров Президенту не должен был предлагать Председатель Правительства. Конституция, закрепляя норму о предложениях премьера по кадровому составу Правительства, как бы предполагает, что подбор членов кабинета осуществляется на основе итогов парламентских выборов и (если отсутствует явное партийное большинство) последующих политических договоренностей между парламентскими фракциями о составе кабинета. Тем самым и сам премьер, и члены правительства предстают как самостоятельные политические фигуры. Однако это предположение оборачивается откровенным лукавством: ни парламентские фракции никак не влияют на подбор кандидатуры премьера, ни сам премьер не становится самостоятельным политиком: Конституция обрисовывает процедуру назначения Председателя Правительства таким образом, что оно зависит не от Государственной Думы, а только от Президента.

Неординарные условия могут заставить Президента отказаться от навязывания Думе определенной кандидатуры. В постсоветской истории это случилось один раз, когда после обрушения «пирамиды государственных казначейских обязательств» («дефолта») 17 августа 1998 г. был отправлен в отставку Председатель Правительства С.В. Кириенко и Президент Б.Н. Ельцин внес в Государственную Думу кандидатуру В.С. Черномырдина, снятого весной того же года с должности Председателя Правительства без видимых причин. Однако два раза депутаты проголосовали против его нового назначения на должность премьера. И тогда Президент, понимая, что на фоне социального шока от дефолта внеочередные выборы могут привести к появлению почти полностью «красной» Думы, согласился внести неофициально предложенную думским большинством кандидатуру Е.М. Примакова. Но даже если политические обстоятельства вынуждают российского Президента пойти на уступки депутатскому большинству, премьер не будет застрахован от произвольной отставки Президентом 
(ч. 2. ст. 117 Конституции РФ). Действительно, кабинет Примакова был отправлен в отставку уже в мае 1999 г.

Зависимость Правительства от Президента в еще большей мере подтверждается (укрепляется) в связи с конституционными основаниями для отставки кабинета и его членов. С одной стороны, Президент вправе по любому поводу (или даже без всякого видимого повода) и в любое время отправить Правительство в отставку. С другой стороны, формален институт недоверия/доверия Государственной Думы Правительству. Показателем этого является то, что за все годы существования Конституции ни один кабинет не был отправлен в отставку в связи с вотумом недоверия или отказом в выражении доверия.

В этой связи мне трудно согласиться с С.М. Шахраем - по его же признанию, одним из авторов конституционного текста. В интервью 2018 г. он сказал: «Смотрите, что у президента? У него все полномочия - на случай конфликта. Может сидеть на печи, но заспорили парламент и правительство - надо с печи слезать и менять парламент или менять правительство. Случился конфликт в регионе - надо слезать с печи и отдавать дело в суд или вводить войска. То есть повседневных функций у нашего президента в Конституции нет. Просто у нас традиция такая была у всех премьеров в истории - прятаться за спиной президента и не нести ответственности за непопулярные решения»[50]. Во-первых, не очень понятно, о каком именно тексте говорит Шахрай. Он был соавтором (руководителем рабочей группы) как «инициативного» проекта 1992 г. («Вариант 0»), так и официального президентского проекта (май 1993 г.) [1], ставшего основой для обсуждения на Конституционном совещании летом 1993 г. А ведь конструкции власти в них существенно разнились: если в «инициативном» проекте довольно явно выписывалась президентская модель (президент глава исполнительной власти), то в президентском - полупрезидентская. В этом проекте действительно президент представал фигурой, близкой к нейтральной. И, во-вторых, С.М. Шахрай говорит о конструкции активной политической борьбы («заспорили парламент и правительство»). Но в том и беда, что наша Конституция не предусматривает споров между парламентом и правительством и, соответственно, модели «президент на печи». Ее уже практически не было после обсуждения президентского проекта на Конституционном совещании. А в связи с доработкой этого проекта в октябре-ноябре 1993 г., ставшего затем действующей Конституцией, ее следы окончательно стерлись: в нашей конституционной конструкции Правительство не имеет своей политической субъектности. И палаты Федерального Собрания РФ (прежде всего Государственная Дума) могут спорить вовсе не с Правительством, а с самим Президентом (это, правда, было заметно лишь при Б.Н. Ельцине). 
2. Часть 4 ст. 78 возлагает на Президента и Правительство одну и ту же функцию: «Президент Российской Федерации $u$ Правительство Российской Федерации обеспечивают в соответствии с Конституцией Российской Федерации осуществление полномочий федеральной государственной власти на всей территории Российской Федерации». Но по Конституции у Президента нет для осуществления этой функции прямых властных полномочий, разве только право «приостанавливать действие актов органов исполнительной власти субъектов Российской Федерации в случае противоречия этих актов Конституции Российской Федерации и федеральным законам, международным обязательствам Российской Федерации или нарушения прав и свобод человека и гражданина» (ч. 2 ст. 85). Но это полномочие далеко не охватывает все возможные ситуации. Следовательно, Президент для исполнения данной функции должен действовать посредством использования сил и средств исполнительной власти.

Таким образом, Правительство рисуется Конституцией РФ не более чем подручный орган Президента. Неудивительно, что и западные компаративисты, тот же Р. Леже, которого нельзя заподозрить в стремлении оправдать существующую систему, отмечают: Конституция РФ наделяет российского Президента «значительными полномочиями, делая из правительства орган по проведению ключевых решений, которые лишь отчасти являются его собственными» [38, с. 212].

И все же такая теснейшая связь президента с правительством не означает, будто глава государства является руководителем исполнительной власти.

Кадровые полномочия сами по себе не могут считаться признаком руководства исполнительной властью. В парламентской системе, а также в полупрезидентских республиках с сильным влиянием парламента глава государства тоже обладает набором таких полномочий (в данном случае неважно, что обычно он осуществляет их не по своему выбору). К тому же президенты имеют кадровые полномочия и в отношении судебной власти, но от этого не становятся ее частью.

Если же в качестве аргумента напомнят о праве Президента РФ «председательствовать на заседаниях Правительства Российской Федерации» (п. «б» ст. 83), то и он не является убедительным. Этот институт был заимствован из Конституции Франции. Но сам по себе он довольно странный. Особенно на фоне концепции «президент-арбитр», о которой мы еще поговорим. Но в любом случае это лишь дополнительное средство в системе рычагов президентского контроля над кабинетом. О его искусственности и слабом практическом значении говорят следующие факты. Вопервых, такое полномочие не было продуманной частью общей системы: лишь перед подписанием проекта Конституции (8 ноября 1993 г.) для его официального опубликования Б.Н. Ельцин своей рукой, но явно по чьему- 
то совету, добавил в ст. 83 упомянутый пункт о возможности председательствовать [9, с. 64]. А во-вторых, за все время действия Конституции РФ 1993 г. президенты лишь считанные разы использовали данное право.

В качестве еще одного аргумента в пользу отнесения Президента РФ к исполнительной власти приводят непосредственное подчинение ему некоторых органов исполнительной власти. Действительно, согласно ст. 32 Федерального конституционного закона «О Правительстве Российской Федерации», он «руководит деятельностью федеральных органов исполнительной власти, ведающих вопросами обороны, безопасности, внутренних дел, юстиции, иностранных дел, предотвращения чрезвычайных ситуаций и ликвидации последствий стихийных бедствий, деятельности войск национальной гвардии Российской Федерации, утверждает по представлению Председателя Правительства Российской Федерации положения о них и назначает руководителей и заместителей руководителей этих органов, а также осуществляет иные полномочия как Верховный Главнокомандующий Вооруженными Силами Российской Федерации и Председатель Совета Безопасности Российской Федерации». Однако конституционность законодательного подчинения Президенту этих органов (сегодня их порядка 20) весьма сомнительна. Прежде всего, с позиций принципа разделения властей. Между прочим, в первоначальной редакции ст. 32 формулировка была гораздо более корректной: «Президент Российской Федерации как Верховный Главнокомандующий Вооруженными Силами Российской Федерации и Председатель Совета Безопасности Российской Федерации в соответствии с Конституцией Российской Федерации, федеральными конституционными законами, федеральными законами своими указами и распоряжениями направляет деятельность <...», а руководство соответствующими органами оставалось за Правительством РФ ${ }^{1}$. Безусловно, указанные в ст. 80 Конституции РФ задачи (функции) Президента по гарантированию норм Конституции, прав и свобод человека и гражданина, охране суверенитета, независимости и государственной целостности страны требуют подконтрольности соответствующих госорганов. Но не в форме прямого руководства/подчинения.

Еще более сомнительно с правовой точки зрения отнесение самим Президентом к исполнительной власти сугубо вспомогательных органов, составляющих, по сути, часть президентского аппарата. Прежде всего имеется в виду Управление делами Президента РФ, наделенное статусом федерального агентства (а это один из трех видов федеральных органов

\footnotetext{
1 Эта редакция Закона была изменена всего спустя две недели после его принятия Федеральным конституционным законом от 31 декабря 1997 г. № 3-ФКЗ «О внесении изменений и дополнений в Федеральный конституционный закон “О Правительстве Российской Федерации"».
} 
исполнительной власти $)^{1}$. Дело, однако, не только в этом статусе, но и в функциях. Среди основных задач Управления значатся: материальнотехническое обеспечение деятельности не только Президента и его Администрации, но и, в частности, Правительства РФ, обеих палат Федерального Собрания РФ, аппаратов Конституционного и Верховного судов РФ, Центризбиркома, Счетной палаты РФ; сочиально-бытовое обслуживание, а также обеспечение жилыми помещениями лиц, замещающих государственные должности РФ; оказание медищинской помощи и организация санаторно-курортного лечения и организованного отдыха этим лицам и сотрудникам их аппаратов, их автотранспортное обслужсивание и т.д. ${ }^{2}$ Вряд ли нужно доказывать, что такой статус и такие функции Управления делами противоречат принципу разделения властей.

Конечно, не приходится спорить с тем, что вообще все, а не только официально подчиненные российскому Президенту органы исполнительной власти (причем в наши дни и федеральные, и региональные), их руководители считают именно Президента своим «начальником». Однако является ли это основанием для теоретического оправдания такого положения? Тут мы сталкиваемся с дилеммой: должны ли теоретикиконституционалисты следовать существующему порядку вещей или всетаки различать, где речь идет о своеобразии модели разделения властей, а где - о дисбалансе властных прерогатив вследствие конституционно установленной конструкции или злоупотребления конституционными полномочиями? Для меня ответ очевиден: вульгарный позитивизм делает вообще ненужной науку конституционного права. Впрочем, тогда это будет уже не наука. Ведь коль скоро мы рассуждаем в рамках конституицинного права, то не можем игнорировать принципы, имманентные этой отрасли. А если так, то обязаны анализировать и оценивать действительность, в том числе законы, с точки зрения этих принципов.

Конституционалисты, разумеется, не должны абстрагироваться от фактического положения вещей. Но, повторю, это не означает, что только оно является основой для принципиальных теоретических выводов. Ведь реальное положение вещей, каким бы привычным ни казалось, может противоречить идее конституционализма. А нынешнее положение президентов во многих полупрезидентских республиках таково, что они действи-

\footnotetext{
${ }^{1}$ Причина понятна: в период драматического противостояния 1992-93 гг. Верховный совет РФ, не желая зависеть от исполнительной власти, которую в ту пору официально возглавлял президент, создал свои охранные и обеспечительные структуры. Поэтому осенью 1993 г. все они были централизованы под началом Президента РФ.

${ }^{2}$ Положение об Управлении делами Президента Российской Федерации, утв. Указом Президента РФ от 17 сентября 2008 г. № 1370 «Об Управлении делами Президента Российской Федерации».
} 
тельно выступают как патроны самой могущественной ветви власти - исполнительной и подчиняют (по крайней мере стремятся подчинить) ее могущество своим интересам. Разумеется, такому подчинению могут воспрепятствовать сильные законодательная и судебная власти, наконец (или - в первую очередь), само общество. А если препятствий нет?..

\section{Концепция президентской ветви власти}

Среди отечественных конституционалистов существует и позиция, согласно которой Президент России не входит ни в одну ветвь власти. Он возвышается над всеми публично-властными институтами [см., например: $21 ; 23$, с. $10 ; 44$, с. $5 ; 49$, с. $1 ; 66$, с. 25-27]. Однако здесь я не стану подробно анализировать аргументы в пользу такой позиции и подвергать их критике. С одной стороны, в силу очевидности того, что трудно придумать что-то более оправдывающее режим личной власти, чем концепт «возвышения», «интегрирующего начала», «объединяющего центра» и т.п. в отношении президента. С другой стороны, если бы я углубился в критику такой позиции, параметры статьи не позволили бы мне попытаться доказать, что президент в смешанной модели представляет собой отдельную ветвь власти.

К этой мысли я склонялся довольно давно [33, с. 399], однако, поначалу интуитивно. И впоследствии не раз сомневался в ее правильности. Но постепенно пришел к выводу, что такая ветвь власти существует и должна быть признана. Смысл такого признания будет означать признание того, что президент не возвышается над «триадой властей», а взаимодействует с органами каждой из «традиционных» ветвей власти, не только имея свои сдержки и противовесы, но и подвергаясь легальному воздействию со стороны других публично-властных институтов.

К настоящему времени появилось немало работ, авторы которых также считают оправданным существование самостоятельной президентской ветви власти [см., например: 12 , с. $11-12 ; 15$, с. $67 ; 16$, с. $8-9 ; 19$, c. $14-15 ; 25$, c. $219 ; 26$, c. $19 ; 31$, c. $433-444 ; 46$, c. 37,$40 ; 48$, c. $22,29,101$; 51$, с. 163,$171 ; 61$, с. 83,95$]$. Правда, с некоторыми аргументами и оценками не могу согласиться. Так, С.Г. Паречина, верно указав, что нынешнее представление об институте президентства как о новой ветви власти - по сути вариация учения Б. Констана о четырех властях, модифицированная к республиканской форме правления, в то же время считает, что президент стоит над остальными институтами государства [48, с. 21-22].

Л.И. Дмитриева выводит существование президентской ветви власти (в России) из «фактического места Президента в системе органов государственной власти» [16, с. 8-9]. Могу только повторить: по меньшей ме- 
pe, странно обосновывать доктринальный тезис принципиального характера сложившейся политической и управленческой практикой, не подвергая оценке, насколько она соответствует Конституции и самому принципу разделения властей $[61$, с. 76$]$. Такая аналитическая основа искажает и сам вывод, ибо далее исследовательница пишет, что «глава государства, по существу, де-факто возглавляет исполнительную власть» [16, с. 10], и в то же время утверждает, что нет оснований «трактовать президентскую власть как стоящую над другими ветвями власти, поскольку каждая из них осуществляет свои конституционно закрепленные за ней полномочия, функционирует во взаимодействии с другими властями, обеспечив определенными рычагами влияние на иные власти и на Президента» [16, с. 10]. В таком случае как возможно, чтобы президент олицетворял самостоятельную ветвь власти и в то же время «фактически» возглавлял исполнительную власть? Такое можно представить, пожалуй, лишь в рамках старинной концепции, согласно которой сам монарх не подпадает под действие принципа разделения властей, но «под монархом» государственные органы действуют на основе этого принципа.

Наиболее основательные аргументы в пользу президентской власти в смешанной модели как «особой ветви государственной власти» выдвинул В.Е. Чиркин. Они сводятся к следующему.

1. «Ветвь власти - это относительно обособленная организационнофункциональная система в целостном государственном механизме, органы и должностные лица которой самостоятельно и в сотрудничестве с другими реализуют определенную частичную функцию государственного управления при осуществлении закрепленных за ними полномочий, не подчинены органам других ветвей государственной власти и применяют в своей деятельности специализированные формы, методы и процедуры» [61, с. 79]. Проще говоря, мы понимаем, что перед нами отдельная ветвь власти, если государственный орган (система органов) имеет свои специфические задачи (предназначение) в системе публичной власти и осуществляет свои функции и полномочия самостоятельно и своими методами, но при этом вступает во взаимоотношения с органами других ветвей власти на основе системы сдержек и противовесов. Этому определению институт президента полностью соответствует.

2. В мировой конституционно-правовой доктрине и практике произошли принципиальные изменения с тех пор, как появилась концепчия разделения властей. В своей более ранней работе В.Е. Чиркин верно заметил, что «концепция разделения властей, являющаяся непреложным постулатом демократии, имеет прежде всего ориентирующий характер и нигде, по крайней мере в современных условиях, не осуществляется и, видимо, не может быть осуществлена в “чистых” формах» [62, с. 15-16]. 
Я бы хотел продолжить его мысль. Собственно говоря, уже Конституция США отличалась от «классической» хотя бы потому, что ни Дж. Локк, ни Ш. Монтескье не знали института президента. Но более суровому испытанию универсализм принципа разделения властей подвергся с появлением парламентской, а затем смешанной систем. Перед конституционно-правовой наукой и политической практикой фактически даже встал вопрос: так ли уж обязателен для демократического и правового государства этот принцип?

Как пишет Р. Альберт, «теория конституционного права долгое время утверждала, что разделение властей - атрибут исключительно государств с президентской формой правления, в парламентских же республиках оно невозможно. Со временем такой подход прочно укоренился по мере разрастания научных споров о сравнительных достоинствах президентских и парламентских систем в условиях молодых демократий или реформируемых государств» [4, с. 32$]$.

Естественно, главным примером, приводимым в пользу отсутствия универсализма принципа разделения властей, стала британская парламентская модель. С одной стороны, вряд ли кто будет спорить с тем, что современная Великобритания является государством демократическим и правовым. С другой стороны, британская система предполагает «персональное слияние институтов исполнительной и законодательной власти», активное фактическое нормотворчество, осуществляемое судами, а судебную деятельность - иногда органом законодательной власти [13, с. 29]. Неудивительно, что одни исследователи считают, будто «разделение властей неприменимо к британской конституции», другие - что вообще «разделение властей основывается на ошибке: не существует естественного разделения властей между тремя ветвями государственной власти» $[8$, с. 9].

И все же принцип разделения властей универсален. Правы те исследователи, которые исходят из того, что идея разделения властей отнюдь не предполагает ни точно установленного числа ветвей власти, ни жестко очерченного круга функций и полномочий каждой из них. Поэтому и британскую систему они не исключают из-под действия принципа разделения властей. Р. Альберт признает, что британская система не отвергает принципа разделения властей, хотя называет это «не совсем традиционным механизмом разделения властей» [4, с. 50-51]. Думается, здесь более точен молодой российский исследователь А. Бруслик: «Факт персонального слияния парламента и правительства, находящийся на поверхности соотношения ветвей власти, часто ошибочно воспринимается и трактуется учеными. Правительство является политическим центром принятия управленческих решений, который одновременно обеспечивает тесную кооперацию между исполнительной и законодательной властью. Настоя- 
щеее разделение между этими властями имеет неявный, глубинный характер» [13, с. 29].

3. Третий довод В.Е. Чиркина звучит так: «Органы создаются для осуществления функции. Функция ветви власти первична, организация последней - вторична. И то и другое определяется правовыми актами государства, прежде всего конституцией. Поэтому, когда мы рассматриваем правовой институт главы государства и пытаемся определить его место в системе других ветвей власти и иных органов, главным в таком юридическом подходе являются правовая функция главы государства, полномочия, предусмотренные конституцией, независимо от того, осуществляются они фактически или нет» [61, с. 75].

Совершенно верный подход: попытки «присоединить» президента к какой-то из трех традиционных ветвей власти не учитывают, что у современного президента (по крайней мере в парламентской и смешанной моделях) видоизменились функции и полномочия в сравнении с европейским монархом XVII-XVIII вв. Поэтому В.Е. Чиркин, ставя вопрос «не следует ли при классификации ветвей государственной власти исходить сначала из функционального критерия, а затем из организационного?», обоснованно отвечает на него: «При таком подходе некоторые прежние ветви власти останутся, но могут появиться новые, отражающие новые функции тех или иных звеньев государственного аппарата» [61, с. 75].

Соглашаясь с таким подходом, я бы только хотел уточнить, что правильнее говорить не о функциях, а о предназначении института. Функции разных институтов как раз могут иногда совпадать, особенно если они закрепляются в общей форме (я уже приводил пример ч. 4 ст. 78 Конституции РФ, согласно которой и Президент, и Правительство обеспечивают осуществление полномочий федеральной государственной власти на всей территории страны). Однако об этом элементе в определениях компетенции государственных органов, как правило, не упоминается.

Наиболее распространенное определение компетенции сводится к тому, что это - совокупность предметов их ведения и соответствующих этим предметам полномочий [24, с. 324]. Правда, эти два элемента разными авторами варьируются. Так, Ю.А. Тихомиров говорит о компетенции как «совокупности властных полномочий, с указанием подведомственности» [57, с. 138] («подведомственность» можно считать синонимом «предметов ведения»). Правда, в более поздней работе он добавил такие элементы, как нормативно установленные цеели и ответственность за неисполнение властных полномочий [58, с. 186]. Однако «цели» деятельности далеко не всегда указываются при закреплении правового статуса того или иного института. Да и нужно ли (и возможно ли) их юридически определять? Например, кто возьмется исчерпьвающе определить цели деятельности парламента или президента? Впрочем, Тихомиров под «целя- 
ми» имеет в виду «длительную нормативную ориентацию», т.е. «публичные функции в широком смысле» [58, с. 187]. Это приближает понятие «цели» к понятию «предназначение», но последнее представляется более точным для понимания смысла существования того или иного государственного органа. Что же касается «ответственности», то ее вообще нельзя считать частью компетенции. Осознание ответственности (иногда это обозначают терминами «позитивная» или «проспективная ответственность») или «внутреннюю ответственность» невозможно правовым образом урегулировать, а реализация ответственности (наложение мер) составляет часть компетенции другого государственного органа.

Не кажется точной и дефиниция В.И. Фадеева, согласно которой компетенция государственного органа есть «совокупность полномочий в установленной сфере деятельности» [32, с. 322]. Конечно, понятие «сфера деятельности» шире, чем «предметы (круг) ведения» или «подведомственность». Но что считать «сферой деятельности», например, парламента или правительства? Осуществление, соответственно, законодательной и исполнительной власти? В таком случае следовало бы говорить и о сфере судебной деятельности. В том и дело, что термин «сфера» («область») в публично-правовом контексте традиционно обозначает не вид деятельности, а содержательно специфические вопросы (оборона, жилищное строительство, образование, космические исследования и т.д.).

Думается, даже над исследователями-конституционалистами довлеет административно-правовая теоретическая традииия. Возможно потому, что классики конституционного права, выстраивая разные теории государственных органов, говорили больше о природе последних, не углубляясь в понятие компетенции. Например, Дюги, разграничивая государственные органы на «представителей» и «агентов» ${ }^{1}$, определял компетенцию просто как «принадлежащую чиновнику власть на совершение того или другого акта, связанного с миссией, выпадающей на долю государства» [17, с. 628]. Но в том и дело, что у органов-«представителей» есть своя миссия (предназначение), обеспечивающая вместе с другими органами общую миссию государства.

Таким образом, можно утверждать, что существует в некотором смысле иерархия элементов компетенции. Функции государственного органа предопределяются его предназначением. Вообще взятые в совокупности «предназначение» и «функции» замещают собой понятие «предметы ведения», что позволяет более строго отделить компетенцию одного

\footnotetext{
1 «Представители, или органы представительства, суть те, которые выражают волю вместо нации, и воля которых такова, как если бы она исходила непосредственно от нации», а «агенты состоят под властью и контролем органов представительства; им совершенно чужд характер представительства, т.е. они совершенно не выражают волю нации» [17, с. 376-377].
} 
органа (и даже ветви власти) от других. А полномочия должны соответствовать и предназначению, и функциям органа власти.

Исходя из сказанного, конституционно-правовую компетенцию государственного органа можно определить как совокупность полномочий, соответствующих его функциям, которые, в свою очередь, соответствуют предназначению данного органа в рамках установленной конституцией системы публичной власти. При таком понимании компетенции появляется возможность разграничить компетенцию и место в системе публичной власти государственных органов, чьи функции частично совпадают.

Понятно, что предназначение Правительства и Президента РФ разное, и это обстоятельство служит основанием, с одной стороны, для вывода о том, что Президент не входит в состав исполнительной власти, с другой - что институт президента образует самостоятельную ветвь власти. С таких позиций можно, разумеется, сказать, что и прокуратура, если исходить из российской Конституции, образует самостоятельную ветвь власти. Возможно, это так, хотя в мире, как правило, органы прокуратуры включаются в состав исполнительной власти. Любопытно, однако, заметить, что в России прокурорские органы, так же как и органы исполнительной власти, находятся «под патронажем» Президента. Но это лишний раз свидетельствует о том, что из фактического положения дел нельзя делать глубокие теоретические выводы, ибо такое положение может означать (а в нашем случае означает) искажение конституционной модели.

В чем же состоит предназначение президента в полупрезидентской республике? Если мы скажем: президент - глава государства, то не скажем ничего. Понятие «глава государства», как уже было показано, слишком неопределенно, слишком нагружено совершенно разными проявлениями, зависящими не только от формы правления или ее разновидности, но и от конституционной конструкции власти в конкретном государстве. Но тогда в чем предназначение?

В каком-то смысле сама Конституция России отвечает на этот вопрос, именуя Президента в ст. 80 гарантом Конституции [22; 65] $]^{1}$ (добавление, что он является также гарантом «прав и свобод человека и гражданина», лишнее, так как понятие «гарант Конституции», безусловно, охватывает и гарантии конституционного режима правового положения личности). Все дело, однако, в том, что некоторые конституционные функции и полномочия российского Президента при системном их рассмотрении не просто выходят за рамки названного предназначения, но

\footnotetext{
1 Это, на мой взгляд, не означает, что орган конституционной юстиции не может быть еще одним гарантом. Но не желая уходить от темы, ограничусь утверждением, что вполне можно было бы примирить взгляды К. Шмитта и Г. Кельзена, споривших по поводу того, кому быть гарантом.
} 
противоречат ему и, главное, фактически ликвидируют возможность подлинного гарантирования Конституции.

\section{Список литературы}

1. Авакьян С.А. Конституция России: Природа, эволюция, современность. - 2-е изд. - М.: РЮИД: «Сашко», 2000. - 426 с.

2. Автономов А.С. Конституционное (государственное) право зарубежных стран: Учебник. - М.: ТК Велби: Проспект, 2005. - 560 с.

3. Алексеев С.С. Теория права. - 2-е изд. - М.: БЕК, 1995. - 320 с.

4. Альберт Р. «Выгоды», доступные президентским республикам, в условиях парламентских демократий // Сравнительное конституционное обозрение. - М., 2011. - № 3. С. 32-58.

5. Аристотель. Политика // Платон, Аристотель. Политика. Наука об управлении государством. - М.: ЭКСМО; СПб.: Terra Fantastica, 2003. - С. 154-492.

6. Арутюнян А.Ш. Конституционно-правовой статус президента Республики Армения: дис. ... д-ра юрид. наук. - М., 1997. - 372 с.

7. Баев В.Г., Ковальски Е.С.Ч. Европейский конституционализм Германии и Польши (Опыт историко-теоретического анализа): Монография / под ред. С.А. Комарова. СПб.: Изд-во Юридического института, 2011. - 392 с.

8. Барбер Н.У. Разделение властей и Конституция Великобритании // Право: Журнал Высшей школы экономики. - М., 2012. - № 1. - С. 3-17.

9. Батурин Ю.М. Конституционные этюды. - М.: Институт права и публичной политики, 2008. $-114 \mathrm{c}$.

10. Бахрах Д.Н., Россинский Б.В., Старилов Ю.Н. Административное право: Учебник для вузов. - 2-е изд. - М.: Норма, 2005. - 816 с.

11. Бельский К.С. Разделение властей и ответственность в государственном управлении. М.: Изд-во Всесоюзного юридического заочного института, 1990. - 169 с.

12. Бобракова Н.В. Институт главы государства в странах СНГ: Сравнительно-правовой анализ: автореф. дис. ... канд. юрид. наук. - Саратов, 2008. - 27 с.

13. Бруслик А. Парламент Великобритании и его взаимосвязь с исполнительной властью // Сравнительное конституционное обозрение. - М., 2016. - № 1. - С. 24-38.

14. Васильева С.В., Виноградов В.А., Мазаев В.Д. Конституционное право России: Учебник. - 2-е изд. - М.: ЭКСМО, 2011. -560 с.

15. Дегтев Г.В. Становление и развитие института президентства в России: Теоретикоправовые и конституционные основы. - М.: Юристъ, 2005. -237 с.

16. Дмитриева Л.И. Президент Российской Федерации в системе разделения властей по Конституции РФ 1993 года // Право: Теория и практика. - М., 2003. - № 12. - С. 5-12.

17. Дюги Л. Конституционное право. Общая теория государства / пер. с франц. А.С. Ященко, В.А. Краснокутского и Б.И. Сыромятникова; с предисл. к русскому переводу проф. П. Новгородцева и автора. - М.: Типография Т-ва И.Д. Сытина, 1908. - 957 с.

18. Залесны Я. Об исполнительной власти Президента Российской Федерации, не являющегося органом исполнительной власти // Studia politologiczne. Режимы постсоветских государств в процессе изменений (на рус. яз.). - Варшава: Институт политических наук Варшавского университета, 2017. - Т. 44. - С. 177-204.

19. Исполнительная власть в России. История и современность, проблемы и перспективы развития. - М.: Новая правовая культура, 2004. - 564 с.

20. Исполнительная власть в Российской Федерации / под ред. А.Ф. Ноздрачева, Ю.А. Тихомирова. - М.: БЕК, 1996. - 269 с. 
21. Кабышев В.Т. Комментарий к статье 11 Конституции РФ // Научно-практический комментарий к Конституции Российской Федерации / под ред. В.В. Лазарева. - М.: Спарк, 1997. - С. 16.

22. Кельзен Г. Кто должен быть гарантом конституции? // Шмитт К. Государство: Право и политика / пер. с нем. и вступ. ст. О.В. Кильдюшова; сост. В.В. Анашвили, О.В. Кильдюшов. - М.: Изд. дом «Территория будущего», 2013. - С. 355-407.

23. Ковалев А.М. Институт президента в системе разделения властей: Сравнительный опыт Франции и России: автореф. дис. ... канд. юрид. наук. - М., 1998. - 17 с.

24. Козлова Е.И., Кутафин О.Е. Конституционное право России: Учебник. - 4-е изд. - М.: ТК Велби: Проспект, 2008. - 565 с.

25. Колюшин Е.И. Конституционное (государственное) право России: Курс лекций. - М.: Изд-во МГУ, 1999. - 381 с.

26. Комарова В.В., Магомедов Ш.Б. Глава государства, региона Российской Федерации. М.: ОКТБ, 1999. $-318 \mathrm{c}$.

27. Кондрашев А.А. Президентский срок: Какая модель ограничения президентских полномочий приемлема для России? // Конституционное и муниципальное право. - М., 2015. - № 10. - С. 57-62.

28. Констан Б. Принципы политики, пригодные для всякого правления // Французский классический либерализм: Сборник / пер. с фр. - М.: Российская политическая энциклопедия (РОССПЭН), 2000. - С. 113-259.

29. Конституционное (государственное) право зарубежных стран: Учебник: В 4-х т. / отв. ред. проф. Б.А. Страшун. - 3-е изд. - М.: БЕК, 1999. - Т. 1/2: Часть общая. - 784 с.

30. Конституционное право России: Учебник / под ред. А.Е. Постникова. - М.: ТК Велби: Проспект, 2007. - $504 \mathrm{c}$.

31. Конституционное право субъектов Российской Федерации / отв. ред. В.А. Кряжков. М.: Городециздат, 2002. - $864 \mathrm{c}$.

32. Конституционное право: Учебник для бакалавров / отв. ред. В.И. Фадеев. - М.: Проспект, 2013. $-584 \mathrm{c}$.

33. Конституция Российской Федерации: Комментарий / под общей ред. Б.Н. Топорнина, Ю.М. Батурина, Р.Г. Орехова. - М.: Юрид. лит., 1994. - 623 с.

34. Коркунов Н.М. Лекции по общей теории права / предисл. проф. И. Козлихина. - 2-е изд. - СПб.: Юридический центр Пресс, 2004. - 422 с.

35. Краснов М.А. Персоналистский режим в России: Опыт институционального анализа. М.: Фонд «Либеральная миссия», 2006. - 180 с.

36. Краснов М.А., Шаблинский И.Г. Российская система власти: Треугольник с одним углом. - М.: Институт права и публичной политики, 2008. -231 с.

37. Кутафин О.Е. Глава государства. - М.: Проспект, 2012. - 560 с.

38. Леже Р. Великие правовые системы современности: Сравнительно-правовой подход / пер. с фр. А.В. Грядов. - 2-е изд. - М.: Волтерс Клувер, 2010. - 584 с.

39. Локк Дж. Два трактата о правлении // Локк Дж. Сочинения: В 3-х т. - М.: Мысль, 1988. Т. 3. $-668 \mathrm{c}$

40. Лучин В.О. Конституция Российской Федерации: Проблемы реализации. - М.: ЮНИТИ-ДАНА, 2002. $-687 \mathrm{c}$.

41. Монтескье Ш. О духе законов // Монтескье Ш. Избранные произведения / под общ. ред.: Баскин М.П. - М.: Госполитиздат, 1955. - С. 159-735.

42. Мишин А.А. Конституционное (государственное) право зарубежных стран: Учебник для вузов. - 17-е изд. - М.: Статут, 2013. -520 c.

43. Нерсесянц В.С. Философия права: Учебник для вузов. - М.: Норма, 2005. - 652 с.

44. Окуньков Л.А. Президент Российской Федерации. Конституция и политическая практика. - М.: ИНФРА-М: Норма, 1996. - 240 с. 
45. Осавелюк А.М. Конституционное право зарубежных стран: Учебное пособие для студентов вузов, обучающихся по специальности «Юриспруденция». - 2-е изд. - М.: ЮНИТИ-ДАНА, 2012. - 511 с.

46. Осетров С.А. Методы реализации президентской власти в Российской Федерации // Конституционное и муниципальное право. - М., 2015. - № 1. - С. 37-40.

47. Основы права: Учебник / под ред. В.В. Лазарева. - М.: Юристъ, 1996. - 472 с.

48. Паречина С.Г. Институт президентства: История и современность / под общ. ред. Е.В. Матусевича. - Минск: ИСПИ, 2003. - 163 с.

49. Радченко В.И. Президент Российской Федерации в системе разделения властей: автореф. дис. ... канд. юрид. наук. - Саратов, 1995. - 19 с.

50. Сергей Шахрай: «Монархия при парламенте... Мы решили эту задачу как Сперанский» // Деловая электронная газета Татарстана «Бизнес Online». - Режим доступа: https://www. business-gazeta.ru/article/372831 (Дата обращения: 19.03.2018.)

51. Современные проблемы организации публичной власти: Монография / отв. ред. Авакьян С.А. - М.: Юстицинформ, 2014. - 596 с.

52. Старилов Ю.Н. Административное право: В 2 ч. - Воронеж: Изд-во Воронежского государственного университета, 2001. - Ч. 2, книга первая: Субъекты. Органы управления. Государственная служба. -624 с.

53. Старилов Ю.Н. Административное право: В 2 ч. - Воронеж: Изд-во Воронежского государственного университета, 2001. - Ч. 2, книга вторая: Формы и методы управленческих действий. Правовые акты управления. Административный договор. Административная юстиция. $-432 \mathrm{c}$.

54. Суворов В.Н. Особенности конституционной регламентации компетенции Президента Российской Федерации // Сб. науч. тр. (межвузовский). - М.: МГИУ, 2000. - Т. 4: Актуальные проблемы социально-гуманитарных наук / под ред. Г.К. Овчинникова. - Режим доступа: http://law.edu.ru/doc/document.asp?docID=1135685

55. Теория права и государства: Учебник / под ред. проф. Г.Н. Манова. - М.: БЕК, 1995. $336 \mathrm{c}$.

56. Тихомиров Ю.А. Курс административного права и процесса. - М.: Юринформцентр, 1998. - 698 c.

57. Тихомиров Ю.А. Публичное право: Учебник. - М.: БЕК, 1995. - 485 с.

58. Тихомиров Ю.А. Современное публичное право: Монографический учебник. - М.: ЭКСМО, 2008. - $446 \mathrm{c}$.

59. Тихомирова Л.В., Тихомиров М.Ю. Юридическая энциклопедия / под ред. М.Ю. Тихомирова. - М.: Юринформцентр, 1997. - 1088 с.

60. Хутинаев И.Д. Институт президента и проблемы формы государства. - М.: Луч, 1994. $40 \mathrm{c}$.

61. Чиркин В.Е. Глава государства: Сравнительно-правовое исследование. - М.: Норма: ИНФРА-М, 2010. - 240 с.

62. Чиркин В.Е. Президентская власть // Государство и право. - М., 1997. - № 5. - С. 15-23.

63. Чичерин Б.Н. Общее государственное право / под ред. и с предисловием В.А. Томсинова. - М.: Зерцало, 2006. -505 с.

64. Чичерин Б.Н. О народном представительстве. - СПб.: Наука, 2016. - 509 с.

65. Шмитт К. Гарант конституции // Шмитт К. Государство: Право и политика / пер. с нем. и вступ. ст. О.В. Кильдюшова; сост. В.В. Анашвили, О.В. Кильдюшов. - М.: Изд. дом «Территория будущего», 2013. - С. 30-220.

66. Шхагапсоев 3.Л. Президент России в системе разделения власти РФ: Место и роль // Общество и право. - Краснодар, 2007. - № 2. - С. 24-30.

67. Wilson W. Constitutional government in United States. - N.Y.: Columbia univ. press, 1917. $236 \mathrm{p}$. 